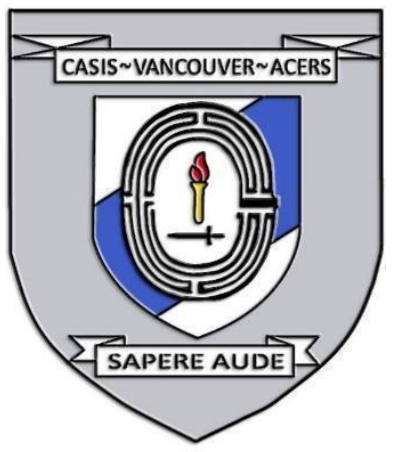

\title{
IMPROVING LAW ENFORCEMENT AND INDIGENOUS RELATIONS
}

Date: February 18, 2021

Disclaimer: This briefing note contains the encapsulation of views presented by the speaker and does not exclusively represent the views of the Canadian Association for Security and Intelligence Studies.

\section{KEY EVENTS}

On February 18, 2021, the Canadian Association for Security and Intelligence Studies (CASIS) Vancouver hosted its second digital roundtable of 2021, where Law Professor, Kent Roach from the University of Toronto presented on Improving Law Enforcement and Indigenous Relations. The presentation was followed by a question and answer period with questions from the audience and CASIS executives.

\section{NATURE OF DISCUSSION}

\section{Presentation}

Professor Kent Roach presented a historical approach to understanding the existing relationship between law enforcement and Indigenous Peoples in Canada. The legacy of colonialism within Canada has contributed to the underprotection and over-policing of Indigenous Peoples within Canada. Professor Roach noted that the continued use of colonial forms of policing, especially within the RCMP, has contributed greatly towards the many problems that Indigenous Peoples within Canada experience. A change in approach towards a more inclusive and holistic form of community safety could improve the safety and security of Indigenous Peoples within Canada.

\section{Question Period}

During the question and answer period, current issues involving the policing of Indigenous communities were discussed as well as current efforts to address racism and diversity in Canadian society and law enforcement. The effectiveness of Community Tripartite Agreement policing agreements was discussed in comparison to Indigenous self-policing programs. 


\section{BACKGROUND}

\section{Presentation}

In Canada, Indigenous Peoples are over-policed and under-protected by law enforcement. Indigenous Peoples are overrepresented in the criminal justice system, making up 30\% of the prison population, while they are underrepresented in other areas including juries and the police force. Additionally, Indigenous issues are often under-investigated by police, as evidenced shown in the Missing and Murdered Indigenous Women and Girls Report published in 2019. This is a result of the legacy of colonialism and racism towards Indigenous Peoples in Canada. Law enforcement in Canada - particularly the RCMP - has traditionally used a colonial model of policing, which involves using a para-military style approach where the local population is viewed as an opposing force. Professor Roach argued that this style of policing contributes greatly to the current problems that Indigenous Peoples experience with policing and that law enforcement should move towards a more community-based approach where the police are seen as part of the public - a style based on Sir Robert Peel's principles of policing, which were implemented by the London Metropolitan Police.

Professor Roach presented evidence of high-profile cases involving Indigenous Peoples, such as the killing of Colten Boushie, who was fatally shot by a Saskatchewan farmer. It demonstrated how polarizing Indigenous policing issues can be in Canada. Issues such as rural defence, gun rights, treaty rights, and racism contribute to this polarization. Additionally, much of the intelligence collected, with respect to Indigenous protests, is collected by police, but their existing policies may not be as sophisticated as other intelligence agencies which may be concerning. However, a potential turning point is developing in Canadian policing. A turn towards a more holistic approach to community safety is required to improve the security of Indigenous Peoples and Canada as a whole. This may involve moving some funding away from expensive policing services towards more mental health professionals and substance abuse experts to deal with situations where law enforcement may have inadequate training. These measures may reduce friction between the public and police and reduce the need for the use of force.

\section{Question Period}

Community Tripartite Agreements between Indigenous communities and the RCMP on policing have not proven to be effective. The main concern with these agreements is that they are not adequately targeted towards the concerns of the

The Journal of Intelligence, Conflict, and Warfare Volume 4, Issue 1 
community. An example of this is an RCMP branch which was subject to that agreement; they tried their best to help the reserve community but found that most of what helped the community came from the local ambulance services. Additionally, recent data has suggested that many RCMP officers operating in Indigenous areas are not Aboriginal or necessarily there by choice. Nevertheless, Professor Roach is more optimistic about self-administered agencies as he believes the police should be democratically responsible to their local community.

During the colonization of Canada, many people believed that they were doing it for the good of the Indigenous Peoples; however, professor Roach finds this thinking disturbing. These beliefs have contributed to white stereotyping of Indigenous Peoples throughout history. Canada needs to consider whether it should continue to perpetuate these inherent biases through a national police force that operates in a para-military structure. Six years after the Truth and Reconciliation Report, we are still not where we need to be in relieving some of the issues caused by colonialism. It will require generations to make changes in a forward direction, and Canada needs to identify barriers between Indigenous Peoples and settler society.

There are some efforts to combat racism in policing across various communities in Canada. For example, the Ontario Human Rights Commission focused on antiblack racism, and a concern is that data on ethnicity in policing has historically not been collected thoroughly. Further reforms are currently being attempted in Edmonton, Winnipeg, Ottawa, and Calgary. Additionally, in Ontario, there is a new policing Act, which proposes that each municipality can develop their own community safety and well-being and that increased use of mental health professional response teams be implemented. However, police culture is hierarchical, and that structure is not ideal for combating existing systems that may facilitate racism within the police force. Raising the percentage of police officers who are minorities is not the only change that is needed; the entire culture of policing needs to be altered.

\section{KEY POINTS OF DISCUSSION}

\section{Presentation}

- The historical colonial model of policing in Canada, mainly implemented by the RCMP, has negatively impacted Indigenous Peoples and their relationship with the criminal justice system. 
- Indigenous Peoples are over-represented among the prisoner population and crime victims in Canada partially because of over-policing and underprotection by law enforcement in their communities.

- The RCMP and other law enforcement agencies in Canada should move towards a community-based approach to policing exemplified by Robert Peel's principles of policing implemented by the London Metropolitan Police.

- High profile cases involving Indigenous Peoples within Canada tend to have a polarizing effect on public opinion.

- A move towards a more community-based approach to policing is required to ensure the safety of Indigenous communities within Canada.

\section{Question and Answer Period}

- The Community Tripartite Agreements have been ineffective in addressing the challenges that Indigenous communities are facing. A program involving self-policing by Indigenous communities would be a more effective method going forward.

- Racism and the colonial history of Canada have contributed to the current injustices involving the policing of Indigenous communities, as well as the para-military nature of the RCMP.

- Recently, there have been increased efforts to improve diversity in police forces in Canada; however, a change in the culture of policing is also needed to address racism in policing.

- Six years after the Truth and Reconciliation Report, we still have not made enough progress in improving relations between Indigenous Peoples and settler colonial society.

\section{(c) (i) ()}

CY NC ND This work is licensed under a Creative Commons AttributionNonCommercial-NoDerivatives 4.0 International License.

(C) (KENT ROACH, 2021)

Published by the Journal of Intelligence, Conflict, and Warfare and Simon Fraser University Available from: https://jicw.org/

The Journal of Intelligence, Conflict, and Warfare Volume 4, Issue 1 